\title{
A blatant disregard of Section 6 (1) of the Constitution of South Africa by higher education institutions and language authorities: An onomastic discrepancy
}

\begin{tabular}{|c|c|}
\hline \multicolumn{2}{|c|}{$\begin{array}{l}\text { Authors: } \\
\text { Tebogo J. Rakgogo } 10 \\
\text { Evangeline B. Zungu² }\end{array}$} \\
\hline \multicolumn{2}{|c|}{$\begin{array}{l}\text { Affiliations: } \\
{ }^{1} \text { Department of Applied } \\
\text { Languages, Faculty of } \\
\text { Humanities, Tshwane } \\
\text { University of Technology, } \\
\text { Pretoria, South Africa }\end{array}$} \\
\hline \multicolumn{2}{|c|}{$\begin{array}{l}{ }^{2} \text { Department of African } \\
\text { Languages, Faculty of } \\
\text { Humanities, University of the } \\
\text { Witwatersrand, } \\
\text { Johannesburg, South Africa }\end{array}$} \\
\hline \multicolumn{2}{|c|}{$\begin{array}{l}\text { Corresponding author: } \\
\text { Tebogo Rakgogo, } \\
\text { rakgogotj@tut.ac.za }\end{array}$} \\
\hline \multicolumn{2}{|c|}{$\begin{array}{l}\text { Dates: } \\
\text { Received: } 06 \text { July } 2021 \\
\text { Accepted: } 02 \text { Dec. } 2021 \\
\text { Published: } 28 \text { Feb. } 2022\end{array}$} \\
\hline \multicolumn{2}{|c|}{$\begin{array}{l}\text { How to cite this article: } \\
\text { Rakgogo, T.J. \& Zungu, E.B., } \\
\text { 2022, 'A blatant disregard } \\
\text { of Section } 6 \text { (1) of the } \\
\text { Constitution of South Africa } \\
\text { by higher education } \\
\text { institutions and language } \\
\text { authorities: An onomastic } \\
\text { discrepancy', Literator } \\
43(1) \text {, a1814. https://doi. } \\
\text { org/10.4102/lit.v43i1.1814 }\end{array}$} \\
\hline \multicolumn{2}{|c|}{$\begin{array}{l}\text { Copyright: } \\
\text { (c) 2022. The Authors. } \\
\text { Licensee: AOSIS. This work } \\
\text { is licensed under the } \\
\text { Creative Commons } \\
\text { Attribution License. }\end{array}$} \\
\hline \multirow{2}{*}{ 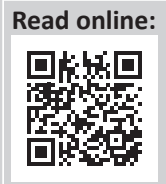 } & \\
\hline & $\begin{array}{l}\text { Scan this QR } \\
\text { code with your } \\
\text { smart phone or } \\
\text { mobile device } \\
\text { to read online. }\end{array}$ \\
\hline
\end{tabular}

The primary focus of this article is the onomastic discrepancies that are considered a blatant disregard of Section 6 (1) of the Constitution of South Africa (Act No. 108 of 1996). The article employs a qualitative research approach where text analysis is used, focusing on constitutional documentation, legislative frameworks on language-related matters and higher education policy documentations, as well as language policy documentation from the selected 10 South African universities that offered Sepedi as a first language or conversational module. It is found that there is a constitutional disregard by competent organisations such as universities, financial institutions, Google and language authorities (such as Pan South African Language Board, Sesotho sa Leboa National Language Body and Sesotho sa Leboa National Lexicography Unit), since most of the policies are inconsistent with Section 6 (1) of the South African Constitution, 1996. In summary, the article records that the policies supersede the Constitution, since the language name 'Northern Sotho/Sesotho sa Leboa' is the most used name to refer to the official standard language rather than its counterpart, Sepedi.

Keywords: onomastic discrepancy; sociolinguistics; language planning; dialect; official standard language; Constitution; higher education institutions and policy deviation.

\section{Introduction}

It is important to mention that the present article will use the name 'Sepedi' and not 'Northern Sotho' nor 'Sesotho sa Leboa' to refer to the official standard language. The reason for this stance is that the Sepedi language name is the one that is supported by the current, legal and valid Constitution (https://www.gov.za/sites/default/files/images/a108-96.pdf) of the Republic of South Africa (Act No. 108 of 1996) after it was promulgated, adopted and amended by the Constitutional Assembly on 11 October 1996.

According to Section 3 (1) of the Interim Constitution of the Republic of South Africa (Act No. 200 of 1993), Afrikaans, English, isiNdebele, Sesotho sa Leboa, Sesotho, siSwati, Xitsonga, Setswana, Tshivenda, isiXhosa and isiZulu must be deemed the official languages of the country. In contrast, Section 6 (1) of the final and present Constitution of the Republic of South Africa (Act No. 108 of 1996) subsequently designated Sepedi, Sesotho, Setswana, siSwati, Tshivenda, Xitsonga, Afrikaans, English, isiNdebele, isiXhosa and isiZulu as the official South African languages.

Critics may argue that the process of replacing the Sesotho sa Leboa name with the Sepedi one in the final Constitution lacked transparency and proper consultation. The reason for mentioning this is that relevant stakeholders, more particularly the first language speakers of the language in question, were not entirely involved when the status type of language planning decision was taken (Parliamentary Joint Constitutional Review Committee, of 2011, 2016, 2017).

It is against this backdrop that the authors argue that the current onomastic discrepancy surrounding both Sepedi and Northern Sotho (Sesotho sa Leboa) language names as official standard names was motivated by the use of different language names in the interim (1993) and final (1996) Constitutions of South Africa. However, it is important to observe that Northern Sotho/Sesotho sa Leboa was only declared an official language in the earlier interim Constitution (1993), whereas Sepedi was recognised instead of Sesotho sa Leboa in the final South African Constitution (1996). In a more logical and philosophical sense, the name Sepedi replaced the 
name Sesotho sa Leboa in the 1996 Constitution, which is deemed the final and conclusive name preferred.

\section{Research problem}

This article problematises the onomastic discrepancy that is realised in constitutional documentation, in legislative frameworks and in Higher Education policy documentation, which disregard Section 6 (1) of the South African Constitution, 1996. In terms of this article, the following are main issues that compound the problem of the current paper: The prima facie evidence on language name contradiction between the interim (1993) and final (1996) Constitutions of South Africa; onomastic discrepancies realised in the translation of the final Constitution and inconsistent language policies of the South African universities on how both Sepedi and Sesotho sa Leboa language names are highlighted to indicate that the two names are concurrently used in official and policy documentation. In a more practical sense, what caught our attention is the consistent use of the name 'Northern Sotho/Sesotho sa Leboa' in official and policy documentation, whereas the Constitution declared 'Sepedi' as one of the 11 South African official languages. Since the Constitution is accepted as the supreme law of the country, it is arguable that all the laws, acts, legislative frameworks, policies, etc. must be in alignment with the constitutional document.

Based on the above-mentioned problem, it can be argued that the lack of compliance, accountability and violation of Section 6 (1) of the Constitution of South Africa form the major qualitative variables to the problem statement of the current article. The above-quoted clause of the Constitution pronounces that Sepedi, Sesotho, Setswana, siSwati, Tshivenda, Xitsonga, Afrikaans, English, isiNdebele, isiXhosa and isiZulu are the 11 official languages of the country, Republic of South Africa. However, there is a consistent deviation, disregard and violation of the above-mentioned clause that is realised in official, informative, descriptive and policy documentation where the Northern Sotho or Sesotho sa Leboa language name supersedes the Sepedi one.

In encapsulation of the problem statement of this article, the authors reiterate that the current article is more concerned with the onomastic discrepancies that are realised in informative, descriptive, policy documentation, as well as in the constitutional documentation. The issue at stake is that Section 6 (1) of the Constitution recognises Sepedi as one of the 11 official languages. However, some of the cited universities, language authorities and financial institutions opted for the Northern Sotho/Sesotho sa Leboa name in official documentation while the Constitution declared Sepedi as an official name. Equally important, it needs to be acknowledged that the issue under attention can also be associated with sociolinguistic and political dynamics. The reason for this submission is that some of the speakers and organisations that reject Sepedi as a language name are arguing that this name is more exclusive as it is associated with a particular ethnic group (Sekhukhune).

\section{Objectives of the study}

Emanating from the onomastic discrepancy surrounding the Sepedi and Northern Sotho/Sesotho sa Leboa language names, the main objectives of the article were to:

- Explore the onomastic discrepancies that are realised in constitutional documentation and other legislative frameworks and also in Higher Education Public Institutions' official and policy documentation.

- Establish how best language planning can help in resolving diverse issues that touch on dialects, ethnic pride and influence of political powers on official standard languages.

- Provide some practical interventions that can be made by the Constitutional Court in consultation with the Constitutional Assembly in an attempt to resolve the mentioned onomastic discrepancies.

\section{Literature review}

\section{An onomastic discrepancy in constitutional and other legislative documentation}

According to Rakgogo and Van Huyssteen (2019:165), after the Constitution of the Republic of South Africa was finalised, it had to be translated from the English source text (in which the language was referred to as 'Sepedi') into all the official languages over a period so that it can support the concept of 'multilingualism'.

A critical irony that may be detected from the translated version of the Constitution is that the heading to the Polity website (http://www.polity.org.za/article/constitution-ofthe-republic-of-south-africa-setswana-version-2008-04-08) indicates the version of the Constitution as Sepedi. Yet Sesotho sa Leboa is recorded as one of the official languages. In a more practical sense, the translated version of the Constitution of the language under scrutiny is entitled the 'Sepedi Constitution' (Rakgogo 2019:35).

It is against this background that the authors confidently state that the onomastic controversy surrounding the names Sepedi and Sesotho sa Leboa is also encompassed in the constitutional documentation, such as the translated versions of the Final Constitution of the Republic of South Africa (1996) where different names were used as a translation equivalent for the name 'Sepedi'. Conclusively, one of the critical questions that may be posed by translators, onomasticians and sociolinguists is whether the use of Sesotho sa Leboa as an equivalent for Sepedi was a translation error or intensional.

\section{South African language authorities deviating from the constitutional name}

The language authorities referred to in the current article are the Pan South African Language Board (PanSALB); Sesotho sa Leboa National Language Body (SsLNLB); Sesotho sa Leboa National Lexicography Unit (SsLNLU) and the Limpopo Provincial Language Council (PLC). It is of crucial importance to note that all the mentioned advisory structures were mandated by the Constitution to oversee and ensure that the 
development of the language under investigation must be recognised officially. Furthermore, these above-mentioned structures are tasked with ensuring that the South African indigenous languages must be fully developed. The default position of the constitutional mandate is that all the dictionaries and spelling and orthography rules will be published with the name 'Northern Sotho/Sesotho sa Leboa' on the cover page.

This article argues that the above-mentioned advisory structures created by PanSALB are using the name, namely Sesotho sa Leboa, and not Sepedi. It is imperative to note that the Sepedi language name is the one that is declared as the official language in Section 6 (1) of the Constitution of the Republic of South Africa. It can further be argued that PanSALB, the one that is considered the mother body of promoting, developing and protecting the officially recognised South African indigenous languages, is also supporting the Sesotho sa Leboa language name while it is not stipulated as an official language in the current, legal and valid South African Constitution (1996). Despite the constitutional mandate and responsibilities, PanSALB opted for the Northern Sotho/Sesotho sa Leboa name to be used in naming the official body, while such name is not supported by the Constitution. It is surprising and dissatisfying to realise that the mentioned language authorities deliberately perplexed the onomastic discrepancy of Sepedi and Northern Sotho/Sesotho sa Leboa instead of providing a clear way forward on how the issue can be resolved.

\section{An onomastic discrepancy in the higher education policy documentation}

From an academic and policy-supported point of view, it can be argued that the South African Higher Education sector intensifies the onomastic problem of Sepedi and Sesotho sa Leboa in policy documentation, instead of using the granted constitutional power of overseeing the language policy for higher education to its advantage in resolving the matter. In terms of this article, it is quite clear that the then Department of Higher Education and Training (now known as Department of Higher Education, Science and Innovation) opted for the Sesotho sa Leboa language name when recording the total number of South African universities (traditional, comprehensive and universities of technology) students and their home language spoken in 2000 as indicated in Figure 1.

Firgure 1 shows how official languages were recorded when the above-mentioned department was conducting a survey on students' profiles. The onomastic discrepancy that is realised in Figure 1 is that the name Sesotho sa Leboa (Northern Sotho) was used to refer to the name of the official language, whereas Section 6 (1) of the Constitution of South Africa recognised and declared Sepedi as one of the 11 official languages.

\section{Higher education institutions and their deviation from the constitution}

The Language Policy Framework for Public Higher Education Institutions, determined in terms of Section 27 (2) of the Higher Education Act, 101 of 1997 as amended, stipulates that Sepedi, Sesotho, Setswana, siSwati, Tshivenda, Xitsonga,
Afrikaans, isiNdebele, isiXhosa, isiZulu and English are the 11 official languages of South Africa as specified in the Constitution of the Republic of South Africa (1996). The most important piece of this legislative framework that is central to the current article is that it is consistent with Section 6 (1) of the Constitution when it comes to Sepedi being an official language, not Northern Sotho/Sesotho sa Leboa.

At the time of writing this article (2021), there were 26 public universities in the Republic of South Africa. The researchers critiqued the language policy of only nine universities, all situated in the north-eastern, inland provinces. It needs to be recognised that these are the universities that offered the language under scrutiny (Sepedi) as a first, second or third (practical or conversational) African language module. Table 2 shows the language names (Sepedi and Northern Sotho/Sesotho sa Leboa), which were used in policy documentation as well as in other official documentation, such as study guides, academic transcripts and prospectuses of the selected mentioned nine South African universities.

Rakgogo (2016:13) stated that in the case of the University of Limpopo, the Ministerial Committee Report on the Development of Indigenous African Languages as Mediums of Instruction in Higher Education (2005:23), recommends that the University of Limpopo must concentrate on the development and use of Northern Sotho/Sesotho sa Leboa, Tshivenda and Xitsonga as media of instruction (University of Limpopo 2005:2).

It is noted that Northern Sotho/Sesotho sa Leboa is declared as one of the African languages that need to be developed in its language policy, and this name is also used in other official documentation such as prospectuses, study guides and academic records. Furthermore, the University of Limpopo has two schools: the School of Languages and Communication Studies and the School of Education, where Sepedi is taught as a subject. However, it is concerning to note that the name 'Sepedi' is used for official use at the School of Education, while, in contrast, the name 'Northern Sotho/Sesotho sa Leboa' is used for official use at the School of Languages and Communication Studies. Having noted that the university

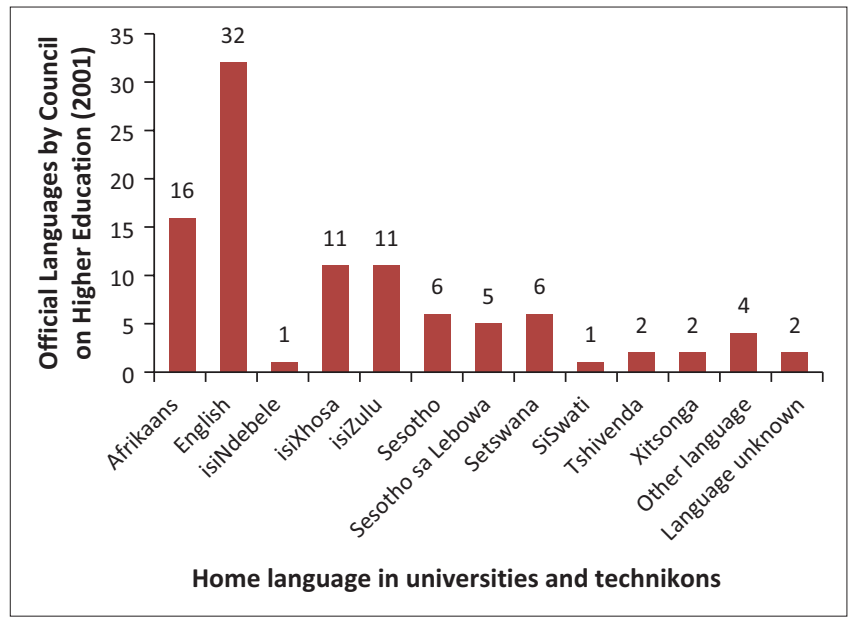

Source: Council on Higher Education (2001)

FIGURE 1: Higher Education Management Information Systems (2000). 
listed Northern Sotho/Sesotho sa Leboa as an official language, critics may argue that the School of Education deviated from its university's language policy, while complying with the Constitution. Similarly, the School of Languages complied with the university's language policy while it disregarded the Constitution.

According to Rakgogo and Van Huyssteen (2018:78), in Tshwane University of Technology (TUT 2005:2) the language name 'Sepedi' is listed as one of the 11 official languages of South Africa, forming part of its language policy. The irony is that the Northern Sotho/Sesotho sa Leboa language name is found in official documentation in the Department of Applied Languages; this implies that the mentioned academic department deviated from its university's language policy, which is in alignment with Section 6 (1) of the South African Constitution.

In terms of this article, it is relevant to note that in the School of Education, the language name 'Sepedi' is found in official documentation, whereas the very same name is the one that is stipulated in the university's language policy, which is consistent with the Constitution and Language Policy Framework for Higher Education. However, the name 'Sotho (North)' is realised in official documentation in the Department of Journalism, while nowhere in the Interim (1993) or Final Constitution (1996) or any other legislative framework is any reference made to Sotho (North). It is against this background that the authors of this article posit that Section 6 (1) of the Constitution of South Africa is being disregarded.

The researchers found that of the nine universities' language policies covered in this article, the University of Pretoria and the University of Mpumalanga appear to be the only two universities that are in alignment with Section 6 (1) of the Constitution of South Africa (Act No. 108 of 1996). In the same vein, some higher education institutions do not entertain the sociolinguistic and onomastic controversy surrounding the language names Sepedi and Northern Sotho/Sesotho sa Leboa as a concomitant part of ethnic pride.

Emanating from the above-mentioned submission, it can be objectively stated that the fact that some institutions and people choose the language name 'Northern Sotho/Sesotho sa Leboa' over 'Sepedi' seems to suggest that they do not regard 'Sepedi' as linked to their 'ethnic pride' or as their 'symbol of identity' since they see 'Sepedi' as an imposition to who they are as Balobedu, Bapulana, Batlokwa, Bahananwa, etc.

Chapter 3 of the Higher Education Act (No. 101 of 1997) touches on the Governance of Public Higher Education Institutions. Section 27 (2) of the above-mentioned Chapter 3 stipulates that:

Subject to the policy determined by the Minister, the council, with the concurrence of the senate, must determine the language policy of a public higher education institution and must publish and make it available on request.
The above-excerpted clause of the Higher Education Act states that all the South African universities (see Table 2) that opted for the Northern Sotho (Sesotho sa Leboa) language name in official and policy documentation are not only violating the Constitution; these universities are also exposing the Council through Senate as prescribed by the act that they must oversee language policy-related issues. The default position of this mandate would be that not only must the language policy of the university be revisited, but the thorough implementation is of paramount importance in ensuring that the universities in question comply with the Constitution of South Africa, 1996. Equally important, it can be mentioned that the relationship between 'Sepedi/Northern Sotho' and the drafting of language policies should be carefully looked into by relevant policy developers in ensuring that the approved language policies are in agreement with the Constitution.

The implication of non-compliance in this context is that the name 'Sepedi' is legally declared an official one in Section 6 (1) of the Constitution, which is contrary to what is captured in informative, descriptive, official and policy documents that are found at these universities. Therefore, it is argued in this article that the onomastic discrepancies surrounding Sepedi and Northern Sotho (Sesotho sa Leboa) are perpetuated by non-compliance by competent organisations.

\section{Financial institutions and their choice of Northern Sotho as an official language name}

In the South African context, users have the opportunity of making financial transactions on an Automatic Teller Machine (ATM). In promoting multilingualism, the system has selected some of the South African official languages to be included on the machine to ensure that people can exercise their linguistic right as to whether they want to operate the machine using English or any other official language that is visible on the screen (Rakgogo 2019:51).

Taking into consideration the fact that the Constitution recognises 11 languages as official, it is important to note that even the financial banks have made sure that at least speakers of different languages are accommodated when operating the machine. However, this exercise may become problematic on its own because it may be interpreted as a violation of those whose languages had not been selected. It can be further argued that there is no language inclusivity since other languages have been excluded without a proper justification.

It is, however, noteworthy to mention that when it comes to the names Sepedi and Sesotho sa Leboa, Sesotho sa Leboa was the name that was opted for even though it is not recognised by the Constitution. The language issue has always been a problematic one, not only in South Africa, but in the entire continent. Therefore, the researchers propose that a proper referral was supposed to be made rather than relying on the assumption that the constitution might have declared Sesotho sa Leboa as an official language. For the 
sake of consistency and compliance, it should be the responsibility of the financial banks to check what is stipulated in Section 6 (1) of the Constitutional documentation, in ensuring that the languages that are selected are also in agreement with the Constitution.

Furthermore, language is a very sensitive issue and it is possible that some speakers may find it insulting to be addressed as Basotho ba Leboa (Sesotho sa Leboa speakers) while they are constitutionally addressed and recognised as Bapedi (Sepedi speakers). Equally important, it is reasonable to acknowledge that Bapedi (i.e. those who self-identify as such) may be insulted by this reference; however, it is also relevant to mention that speakers from other ethnic groups such as Balobedu, Bapulana and Batlokwa may also be insulted when erroneously regarded as 'Bapedi'. Table 2 indicates how the financial banks in a South African context state what is official and what is not.

\section{Google task bar and its recognised official languages}

When using Google to search for information online in South Africa (see https:/ / www.google.co.za/), Google gives one a language bar (as is the case when using Google in other countries). This language bar normally includes some of the official languages recognised in that particular country. In this case, it can be noted that Google opted for the name Northern Sotho (Sesotho sa Leboa), not Sepedi that is cited by the Constitution as one of the official languages.

\section{The onomastic status quo on Sepedi and Sesotho sa Leboa (Northern Sotho) names}

According to Rakgogo and Zungu (2021), the current state of affairs on the onomastic dilemma of the above-mentioned language names has divided the speakers of the language in question into two groups. The official language name 'Sepedi', as stipulated in the Constitution of South Africa (1996), has divided the first language (L1) speakers into two groups. One group is in support of the Sepedi name and the other is rejecting the mentioned language name. Up to now, there have been numerous surveys and parliamentary discussions on the official name of the language in question. In his sociolinguistic survey of selected South African universities that offered the language under attention as a module, Rakgogo (2016) records that the majority (57\%) of the respondents and participants were in support of Sesotho sa Leboa (Northern Sotho) as the name suitable to be included in Section 6 (1) of the South African Constitution, 1996.

In justification of the chosen language name, it was argued that Sepedi is a dialect, not a language. Others cogently argued that the process of replacing the name 'Sesotho sa Leboa' with the name 'Sepedi' was not consultative and transparent. In contrast, those who supported Sepedi as the right name to be maintained in the Constitution argued that Sesotho sa Leboa (Northern Sotho) is a colonial name that was imposed by the colonisers and it undermines the naming practice of the L1 speakers.

This confusion is confirmed by scholars such as Mojela (1997, 1999, 2007), Kretzer (2016), Rakgogo (2016), Rakgogo and Van Huyssteen (2018), Rakgogo (2019), and Rakgogo and Van Huyssteen (2019). Furthermore, the Parliamentary Joint Constitutional Review Committee of 2011, 2016, 2017 and 2020 shared a similar perspective with the researchers, and the members of the above-mentioned committee criticised the replacement of the Sesotho sa Leboa name with Sepedi in the final Constitution without proper consultation with the relevant stakeholders, more particularly the L1 speakers of the language under scrutiny. It is for this reason that L1 speakers from other tribes dispute the suggestion that Sepedi is their L1; they concede that they studied it in school as a Home Language, but that does not make it their L1 because their L1s are Khelobedu, Sepulana, Sehananwa, etc. (Rakgogo 2016).

\section{Effective language planning as a manager of ethnic pride and political powers in a comparable country}

In Rakgogo and Zungu (2021:10), the participants strongly agreed that because of ethnic pride and the misuse of political powers and influence, the onomastic controversy of Sepedi and Sesotho sa Leboa will not end any time soon. It can therefore be interpreted that the research problem that triggered this article cannot be separated from sociolinguistic aspects such as ethnic pride, cultural, economic and political powers.

Kadmon (2013:86) submitted that a politically motivated name replacement can be found in any region that suffered from administrative instability and especially from changes in local regimes. Similarly, Manatsha (2014:275) posited that the process of renaming places, languages, streets and other public entities will remain an ongoing exercise as long as there are social and political 'revolutions'.

According to Porter (2017:47), when Tagalog was recognised as the national language of the Philippines in the 1940s, many of the post-war Presidents and administrations continued to use English in their speeches, thus consigning Tagalog to a secondary position. In 1959, Tagalog was renamed Pilipino to separate the language from the ethnolinguistic group. Furthermore, on 13 August 1959, during the celebration of National Language Week (13-19 August), Secretary of Education Jose E. Romero issued Department Order No. 7, mandating that the national language would henceforth be referred to as Pilipino 'to impress upon the National Language "the incredible character" of Filipino nationhood'.

One should carefully note that from 1939 onwards, when the effectivity of Tagalog as the national language was supposed to take place, the literature henceforth stopped using Tagalog as the name, undoubtedly to forestall any resentments on the 
part of non-Tagalogs. The language was referred to as the Filipino national language (wikang pambansang Pilipino) or simply the national language (wikang pambansa or even wika). As subsequent debates will show, a distinction between Tagalog (a local, vernacular spoken in Luzon) and Tagalogbased Pilipino has become necessary for public relations purposes (so as not to antagonise the non-Tagalog). The use of the name Pilipino was a further step in this direction of super regionalising and, in effect, nationalising what was once a regional vernacular or what was then a current term, dialect (Porter 2017:47).

Touching on the onomastic and sociolinguistic confusion brought by the concurrent use of Sepedi and Northern Sotho (Sesotho sa Leboa) to refer to the same language, it is for this reason that scholars such as Mokgokong (1966), Mönnig (1967), Mojela (1997, 1999, 2007), Kretzer (2016), Rakgogo (2016), Rakgogo and Van Huyssteen (2018), Rakgogo (2019), Rakgogo and Van Huyssteen (2019) and Rakgogo and Zungu (2021) attest that Sepedi was a dialect that was at a later stage escalated to the status of an official language. This was because of the influence of the early missionaries who used Sepedi and Sekopa dialects as the foundational standard language.

It can, therefore, be interpreted that the renaming of the Philippine national language from Tagalog to Filipino was in effect done with the intention for it to be less regional, or less connected to the Tagalog region. In the context of the language under onomastic attention, it is arguable that the onomastic discrepancy of Sepedi and Northern Sotho (Sesotho sa Leboa) names is somehow perpetuated by the fact that other speakers still consider Sepedi as a dialect, not as a standard language. It is against this background that the significant majority (93\%) of the participants opined that the language under onomastic scrutiny (Sepedi) must be renamed in order to restore peace, unity and solidarity among the L1 speakers (Rakgogo \& Zungu 2021:14).

\section{Research design}

In terms of this article, the research design selected for this investigation involved qualitative methods employing qualitative instruments for data collection and analysis.

\section{Research approach}

In this article, the qualitative approach was used to achieve the aims and objectives that the authors attempt to achieve.

\section{Methods of data collection}

Text and document analysis were used as the qualitative methods of data collection. In this quest, constitutional documentation incorporating the interim (1993) and final (1993) Constitution of the Republic of South Africa, the translated versions of the South African Constitution (1996), Joint Parliamentary Constitutional Review Committee (2011, $2017,2020)$ were effectively used. In addition, other legislative frameworks, Government Gazettes, language policies of the nine selected South African universities, as well as language authorities' documentation were incorporated with the ultimate aim of supplementing the aforementioned research data collection instruments. Descriptive analysis and an interpretive paradigm were used as the methods of data collection. The two methods of data analysis gave the researcher an opportunity to directly get responses from some of the participants.

\section{Discussion of the main findings Lack of proper oversight on language policy- related matters by council and senate}

A critical analysis of Chapter 3 of the Higher Education Act (No. 101 of 1997) may suggest that Section 27 (2) of this chapter is not fully applied. It is for this reason that the present study recorded that a significant majority of the South African universities listed in Table 1 opted for the Northern Sotho (Sesotho sa Leboa) language name in policy and official documentation; yet, the Constitution and other legislative frameworks consider Sepedi as one of the South African official languages.

According to the literature review conducted in this article, the Council through the Senate must determine the language policy of a public higher education institution and must publish and make it available on request. This clause implies that both Council and Senate are the immediate cause of oversight and language policy-related matters in each university. It is important to note that some of the universities' language policies are not in alignment with the language names that are found in departmental informative and descriptive documentation. In essence, the article found that some of the universities' policies are consistent with the Constitution of South Africa but the academic departments deviated without a proper justification.

In contrast, the rejection of Sepedi as the official language name by most of the South African universities in policy, informative and descriptive documentation suggests that much needs to be done in ensuring that the language name declared in the Constitution represents views and perspectives of L1 speakers at grass roots level. In terms of this article, it can be stated that the Northern Sotho/Sesotho sa Leboa language name is the most opted for when compared to its counterpart, Sepedi. It is for this reason that Rakgogo (2016, 2019) recorded that a reasonable number of the L1 speakers of the language under onomastic discrepancy do not accept the name 'Sepedi' as their symbol of identity. The reason for this is that the process of replacing Northern Sotho/Sesotho sa Leboa with Sepedi in the final Constitution (1996) was not consultative and it also lacked transparency.

\section{Lack of action by Department of Justice and correctional services and constitutional court}

The current article stipulates that the Constitution (1996) is known and accepted as the supreme law of the country in the 
Republic of South Africa. It is for this reason that PanSALB and the Commission for the Promotion and Protection of the Rights of Cultural, Religious and Linguistic Communities listed in Chapter 9 state that institutions must support and protect the constitutional democracy. However, there was never any intervention from the above-mentioned state institutions that attempted to resolve the onomastic discrepancy of Sepedi and Northern Sotho (Sesotho sa Leboa) in official and policy documentation.

Equally important, the article acknowledges that the matter under attention touches on the Department of Justice and Correctional Services and the Constitutional Court of South Africa. It was found that the current onomastic discrepancy of Sepedi and Northern Sotho (Sesotho sa Leboa) was perpetrated by the drafters and approvers of the Constitution. The authors argue that it needs to be taken into consideration that the Constitutional Assembly was mandated to draft the Constitution while the Constitutional Court was the one that approved the conclusive draft. The current article found that the language change from Northern Sotho (Sesotho sa Leboa) to Sepedi was supposed to be identified and fully addressed before the constitutional document was considered final.

Furthermore, it was found that the above-mentioned language name replacement was unconstitutional. The reason for this is that the process lacked transparency and proper consultancy with the relevant stakeholders. It is against this background that the article proposes that the silence and lack of action by the Department of Justice and Constitutional Development together with the Constitutional Court of South Africa exacerbate the problem.

\section{Northern Sotho (Sesotho sa Leboa) name supersedes the official Sepedi name}

The literature consulted in this article argued that there is extensive and consistent use of the language name 'Northern Sotho/Sesotho sa Leboa' in constitutional, policy, official, informative and descriptive documentation, whereas the South African Constitution (1996) designated Sepedi as one of the official languages. It was found in this study that the Northern Sotho (Sesotho sa Leboa) language name was the one most opted for and used in informative, descriptive, official and policy documentation as indicated in Tables 1 and 2. The authors postulate that a policy cannot supersede the Constitution. The study submits that it is inaccurate and unconstitutional for individuals, private and public organisations, government departments, South African universities, financial banks and Google to use Sesotho sa Leboa (Northern Sotho) as a language name while Section 6 (1) of the South African Constitution (1996) cites Sepedi as the official language, not Sesotho sa Leboa.

If the statistics are being followed, it is clear that the official 'Sepedi' language name is in a disadvantageous position if it were to be compared with the 'Northern Sotho/Sesotho sa Leboa' language name, since most of
TABLE 1: South African universities and their choice of language name.

\begin{tabular}{|c|c|}
\hline University name & Language name in policy documentation \\
\hline 1. University of Johannesburg & Northern Sotho/Sesotho sa Leboa \\
\hline 2. University of South Africa & Northern Sotho/Sesotho sa Leboa \\
\hline 3. University of Pretoria & Sepedi \\
\hline 4. University of Limpopo & Northern Sotho/Sesotho sa Leboa \\
\hline 5. University of Venda & Northern Sotho/Sesotho sa Leboa \\
\hline 6. North-West University & Northern Sotho/Sesotho sa Leboa \\
\hline $\begin{array}{l}\text { 7. Tshwane University of } \\
\text { Technology (TUT) }\end{array}$ & Northern Sotho/Sesotho sa Leboa \\
\hline $\begin{array}{l}\text { 8. University of the Witwatersrand, } \\
\text { Johannesburg }\end{array}$ & Northern Sotho/Sesotho sa Leboa \\
\hline 9. University of Mpumalanga & Sepedi \\
\hline
\end{tabular}

TABLE 2: Financial institutions and their choice of language name.

Name of financial bank Language name opted for

\begin{tabular}{ll}
\hline First National Bank & Northern Sotho/Sesotho sa Leboa \\
\hline Standard Bank & Northern Sotho/Sesotho sa Leboa \\
\hline Absa Bank & Northern Sotho/Sesotho sa Leboa \\
\hline Nedbank & Northern Sotho/Sesotho sa Leboa \\
Capitec Bank & Northern Sotho/Sesotho sa Leboa \\
\hline
\end{tabular}

the organisations cited it as an official standard language. It is for these reasons that the article found that the unofficial Northern Sotho (Sesotho sa Leboa) language name supersedes the official Sepedi name when coming to informative, descriptive, official and policy documentation. It is against this background that the current article postulates that the language name 'Northern Sotho/Sesotho sa Leboa' is preferred to the Sepedi language name.

\section{The interchangeable use of Sepedi and Northern Sotho/Sesotho sa Leboa}

It is fair and reasonable to acknowledge that the inclusion and consistent use of Northern Sotho (Sesotho sa Leboa) may be because of the misconception that the two names under attention (Sepedi and Northern Sotho/Sesotho sa Leboa) mean the same thing. In a more practical sense, the aim was not to support Northern Sotho (Sesotho sa Leboa) or reject Sepedi as an official language; general language users of the language happen to use them interchangeably. To the uninformed speech communities, the two mentioned language names may refer to the same language, while they may mean two different things to the speech community that is following the onomastic and sociolinguistic controversy that is surrounding the two language names under scrutiny.

\section{Language authorities undermine the constitutional democracy}

In this article, it is found that it is inaccurate and unconstitutional for the SsLNLB and the SsLNLU to use the language name that is not official in terms of the South African Constitution (1996) to name the structure that is constitutionally mandated. It emerged that this kind of exercise does not only undermine the integrity of the L1 speakers, but it also violates Section 6 (1) of the Constitution of South Africa. 


\section{The intentional violation of the section 6 (1) of the Constitution}

Critics may concede that those individuals such as scholars who perpetuate the onomastic discrepancy under scrutiny and organisations who are entertaining the sociolinguistic and dialectal politics, are common in the South African context. However, it was revealed in this study that the disregard and violation of the Constitution that causes onomastic discrepancy is unjustified; it is a deliberate effort by those who are not accepting the status of Sepedi as one of the South African 11 official languages, as cited in Section 6 (1) of the Constitution of South Africa. The article recommends that all those who are promoting Northern Sotho (Sesotho sa Leboa) in official and policy documentation should rather adhere to what is stipulated in the above-mentioned clause of the Constitution and use the name Sepedi for the sake of official consistency in the present language planning, sociolinguistic and onomastic context. Thus, at this stage, strictly speaking Sepedi must not be regarded as the name of a dialect that is associated with a particular ethnic group but as the name of an official standard language.

\section{Contradiction between Section 6 (1) and Section 7 (18) of the Constitution, 1996}

In terms of this article, the following languages are cited, pronounced and declared as official languages in Section 6 (1) of the Constitution of South Africa: Sepedi, Sesotho, Setswana, siSwati, Tshivenda, Xitsonga, Afrikaans, English, isiNdebele, isiXhosa and isiZulu. The implications of this clause are that all the universities, language authorities and financial institutions that are mentioned in this article should consistently follow what is stipulated by this clause of the Constitution, more especially within the context of using these languages in official and policy documentation. The extensive use of the name 'Northern Sotho/Sesotho sa Leboa' as the name of the official language may be interpreted as a disregard to the South African Constitution since it acknowledges Sepedi as one of the 11 official languages.

In contrast, Section 7 (18) of the above-quoted Constitution articulates that everyone has the right to freedom of association. The implication of this clause of the Constitution is that the L1 speakers of the dialects or languages (nonofficial) such as Tau, Roka, Kone, Mphahlele, Tšhwene, Mathabatha, Matlala, Dikgale, Mothiba, Nkwana, Molepo, Mamabolo, Tlokwa, Birwa, Kwena, Moletši, Hananwa, Lobedu, Phalaborwa, Nareng, Maake, Mametša, Tlhabine, Pulana, Pai and Kutswe have the right to associate themselves with their ethnic tribes. In terms of this article, two critical questions that are posed to onomasticians, sociolinguists, dialectologists and language planners are:

- Is it right to force other ethnic tribes to associate themselves with the name Sepedi through legislation?

- What is the constitutional meaning of Section 7 (18) that talks about freedom of association in relation to the onomastic controversy surrounding Sepedi and Northern Sotho/Sesotho sa Leboa language names?

\section{Conclusion}

The Constitution of the Republic of South Africa (Act No. 108 of 1996) is known and accepted as the supreme law of the country. It is interesting to note that the Language Policy Framework for Public Higher Education Institutions developed and promulgated in 2002, as determined in terms of Section 27 (2) of the Higher Education Act, 101 of 1997 , is in alignment and consistent with the Constitution. In addition, the Use of Official Languages Act 12 of 2012 is also in support of the South African Constitution when it comes to Sepedi listed as one of the 11 official languages. The article aimed at exploring a blatant disregard of Section 6 (1) of the Constitution by competent organisations such as universities, financial institutions and websites such as Google.

It was found that there is an extensive, consistent and deliberate use of the Northern Sotho (Sesotho sa Leboa) language name in official and policy documentation while the Constitution and other legislative frameworks designated Sepedi as an official language. It is against this background that the article concludes that there is onomastic discrepancy of Sepedi and Northern Sotho (Sesotho sa Leboa) as a direct concomitant part of those organisations that fail to comply with the Constitution. The article recommends that since the issue under attention falls under the jurisdiction of the Department of Justice and Correctional Services together with the Constitutional Court of South Africa, an urgent court order must be issued to all those organisations that are disregarding the above-mentioned clause of the Constitution.

\section{Acknowledgements}

The authors wish to express their sincere gratitude and appreciation to all the universities, government departments and language authorities for allowing the researchers to administer survey questionnaires and interview their staff members during normal working and operational hours.

\section{Competing interests}

The authors declare that they have no financial or personal relationships that may have inappropriately influenced them in writing this article.

\section{Authors' contributions}

The content of this article is partly based on the Master's dissertation (2016) and PhD thesis (2019) of T.J.R. that were completed under the supervision of Linda van Huyssteen and E.B.Z. T.J.R. drafted the article, whilst E.B.Z. revised it, before both of them could finalise it.

\section{Ethical considerations}

Ethical clearance to conduct this study was obtained from the Tshwane University of Technology Research Ethics 
Committee and the University of Witwatersrand Human Research Ethics Committee (No. REC/2015/03/007).

\section{Funding information}

The authors wish to thank the University Development Capacity Grant (TUT), funded by the Department of Higher Education (DHET), for financial support and stability. Equally important is the financial assistance of the National Institute for the Humanities and Social Sciences (NIHSS), in collaboration with the South African Humanities Deans Association (SAHUDA), which is hereby acknowledged.

\section{Data availability}

The data that support the findings of this study are available in the Wits Institutional Repository (WIReDSpace): Wits E-Theses/Dissertations (ETDs) and in the Tshwane University of Technology Open Repository (TUTDoR) at http:/ / tutvital.ac.za:8080/vital/access / manager / Repository/tut:2541/SOURCE1.

\section{Disclaimer}

The views and opinions expressed in this article are those of the authors and do not necessarily reflect the official policy or position of any affiliated agency of the authors.

\section{References}

Department of Higher Education, 2002, Language policy framework for public higher education institutions, Government Printers, Pretoria.

Department of Higher Education, 2005, Ministerial committee report on the development of indigenous African languages as mediums of instruction in higher education, Government Printers, Pretoria.

Government Gazette No. 18515, 1997, Higher Education Act, Government Printers, Pretoria.

Kadmon, N., 2013, 'Toponym and geopolitics: The political use - and misuse - of geographical names', The Cartographic Journal 41(2), 85-87. https://doi. org/10.1179/000870404X12897

Kretzer, M.M., 2016, 'Variations of overt and covert language practices of educators in the North West Province: A case study of the use of Setswana and Sesotho at primary and secondary schools', South African Journal of African Languages 36(1), 15-24. https://doi.org/10.1080/02572117.2016.1186891
Kumar, L., 2014, Research methodology, Sage, London.

Manatsha, T.R., 2014, 'The politics of renaming "colonial" streets in Francistown', Botswana Historia 59(2), 269-288.

Mojela, V.M., 1997, The development of Bantu linguistics, NSOT300 study guide, University of the North, Pietersburg.

Mojela, V.M., 1999, 'Prestige terminology and its consequences in the development in Northern Sotho vocabulary', Unpublished DLitt et Phil thesis, University of South Africa.

Mojela, V.M., 2007, 'Polysemy and homonymy: Challenges relating to lexical entries in the Sesotho sa Leboa-English bilingual dictionary', Lexikos Journal 17, 433-439. https://doi.org/10.5788/17-0-537

Mokgokong, P.C., 1966, 'A dialect-geographical survey of the phonology of the Northern Sotho area', Unpublished M.A. dissertation, University of South Africa.

Mönnig, H.O., 1967, The Pedi, Van Schaik, Pretoria.

Parliamentary Joint Constitutional Review Committee, 2011, Sesotho sa Leboa vs Sepedi, Government Printers, Pretoria.

Parliamentary Joint Constitutional Review Committee, 2016, Public submissions: legal opinions, Government Printers, Pretoria.

Parliamentary Joint Constitutional Review Committee, 2017, Status of Sepedi, Sesotho sa Leboa, Khelovhedu \& Sign Language of South Africa \& Khoi, Nama \& San Languages: Pansalb, DAC \& CRL Rights Commission, Government Printers, Pretoria.

Parliamentary Joint Constitutional Review Committee, 2020, Language submissions: overview, Government Printers, Pretoria.

Porter, C.J., 2017, 'Language, Tagalog regionalism, and Filipino nationalism: How a language-centered Tagalog regionalism helped to develop a Philippine nationalism', Unpublished M.A. dissertation, University of California.

Rakgogo, T.J., 2016, 'A sociolinguistic perspective of first language speakers from the selected South African universities', Unpublished M.A. dissertation, Tshwane University of Technology.

Rakgogo, T.J., 2019, 'Investigating the onomastic principles of naming an official language: The case of the Sepedi and Sesotho sa Leboa (Northern Sotho) language names', Unpublished PhD thesis, University of the Witwatersrand.

Rakgogo, T.J. \& Van Huyssteen, L., 2018, 'Exploring the Northern Sotho language name discrepancies in informative documentation and among first language speakers', South African Journal of African Languages 38(1), 79-86.

Rakgogo, T.J. \& Van Huyssteen, L., 2019, 'A constitutional language name, lost in translation and its impact on the identity of the first language speakers', South African Journal of African Languages 39(2), 165-174. https://doi.org/10.1080/02 572117.2019.1618015

Rakgogo, T.J. \& Zungu, E.B., 2021, 'The onomastic possibility of renaming the Sepedi and Sesotho sa Leboa (Northern Sotho) language names to restore peace, unity, and solidarity', Literator 42(1), a1696. https://doi.org/10.4102/lit.v42i1.1696

Republic of South Africa, 1993, Interim Constitution of the Republic of South Africa, Government Printers, Pretoria.

Republic of South Africa, 1996, Final Constitution of the Republic of South Africa, Government Printers, Pretoria.

The Use of Official Languages Act, 12 of 2012, Government Printers, Pretoria.

Tshwane University of Technology, 2005, Language policy, Tshwane University of Technology, Pretoria.

University of Limpopo, 2005, Language policy, University of Limpopo, Polokwane. 